characters . Horwood's Midland elm, $U$, elegantissima, is a hybrid of this group.

There is a wide field for investigation in the physical properties and economic value of our native elms. Much of the ill-repute with which elm timber is regarded may be due to admixture of unsuitable hybrids. Without botanical assistance both forester and timber merchant may accept inferior hybrids as wych elm, since the habit of this species appears to be a dominant character. Field observations suggest that interaction or recombination of genes occurs in the hybrids, and may result in wood so brittle that branches half an inch in diameter break under slight pressure with a short fracture. On the other hand, it is probable that improved strains for timber production could be selected and this might be coupled with resistance to the Dutch elm disease, Ceratostomella ulmi. Of our native species, the wych elm is the most susceptible, but scme of its hybrids are even less resistant, notably the Dutch elm and many of the heterogeneous forms hitherto imported as seedlings from the Continent. The Cornish elm, the English elm and the Plot elm all appear to be comparatively resistant.

Royal Botanic Gardens,

R. Melvinle. Kew.

1 Howard, A. L., NATURE, 152, 636 (1943).

'Melville, R., J. Bot., 76, 261 (1938).

"Melville, R., $J$. Bot., 76, 185 (1938).

'Melville, R., Proc. Linn. Soc., 151, 152 (1939)

Melville, R., J. Bot., 78. 181 (1940).

-Melville, R., J. Bot., 77', 138 (1939).

Surecy Dr. Melville is misquoting me. My statement was : "There are about twenty speeies, of which only two are prominent in the United Kingdom -the common elm (Ulmus campestris) and the wych elm (Ulmus montana)-with perhaps nine or more hybrids or varieties".

The article contributed by Dr. Melville, who has made a comprehensive study of the elm tree and has published many interesting articles in the Journal of Botany and that of the Lininean Society, recalls to my mind a conversation which took place about forty-two years ago between Henry John Elwes and Sir Hugh Beevor, one of whom at the time was president of the Royal English Arboricultural Society.

The subject was whether the elm was indigenous to Great Britain, and covered much the same ground as that traversed by Melville. It seems difficult to understand that those keen-eyed, closely observant men who came before and followed Evelyn would be likely to have been mistaken. The intelligent woodman clearly recognizes the difference between the common elm, the wych elm and the Dutch, the lastnamed of which assumes a quite different appearance in its habits from either of the others.

There is no doubt that the elm, with the exception of those sorts already mentioned, and possibly the Cornish elm, varies greatly, probably more than any other of our trees.

The regular planting and rearing of English elm has received little attention during the last two hundred years, and the greater majority of those trees that have established themselves have been self-sown. During this period a great many aliens have been introduced into Great Britain-American, Canadian, European, Japanese, etc. Is it possible that this has resulted in the development of hybrids ?

4 Stanhope Street, AlexandFr L. Howard.

\section{An Undescribed Feature in the Drill (Mandrillus leucophaeus)}

GLANDULAR modifications of the skin over the sternal region in primates have been described in the orang (Schultz) and in the Gelada. Something of the kind evidently exists in the drill (Mandrillus leucophoeus) and possibly also, therefore, in the mandrill (M. sphinx), though full details cannot be given pending histological study of the part. No. reference is made to such a structure by Sonntag.

My notice was first directed to the possibility of a sternal cutaneous modification in a male drill which has been in captivity under my observation for seven years. After passing the pubertal epoch at the approximate age of five years, he developed, upon the middle of his chest, between the nipples, a tuftlike patch of specialized hairs. These are longer, coarser, stiffer and of duskier colour than the general ventral covering of short, soft, whitish hairs. They project caudalwards and at times are slightly more upstanding than the hairs of the neighbouring areas.

This hairy tuft is the bas s of a very curious and extremely amusing behavioural pattern which is observed only when the animal is presented with pieces of fresh twig or bark derived from a mango tree (Mangifera indica). After smelling the twig, he rubs it in a vertical direction on his mouth and chin (maximum pressure being on the chin) and swiftly passes it thence to the sternal tuft, thrusting the chest forwards to meet it. This procedure is repeated many times in rapid succession. Each time a return is made from sternum to lips, profuse salivation takes place, until his beard is literally dribbling with saliva, much of which is transferred to the sternal tuft in the frenzied antics accompanying the act. The animal apparently realizes that this behaviour has an entertainment value, and this stimulates him to adopt the most inconceivable bodily postures in an endeavour to obtain the maximum number of contacts between the twig and his chest in the minimum time. The animal is quite rational in his other behaviour, so that $I$ do not consider this to be merely a personal idiosyncrasy.

No adequate explanation can at present be offered for this behaviour; but it is clearly initiated by the characteristic odour of the mango bark (the fruit has no similar effect). Some pleasurable sensation is evidently experienced either $(a)$ from contact between the moistened bark and the sternal tuft, or $(b)$ the twig serves to transfer a possible cutaneous secretion from a gland on the chest to the lips and nose, whereby pleasure is evoked by the taste or smell thereof, or (c) both.

There is no direct evidence of any sexual significance in the specialization here referred to, except that so far it has only been observed in an adult male. I have examined cadavers of two female drills (one juvenile and one sub-adult) and found no modification of the hair, and at any rate no macroscopic indication of a cutaneous gland in the intermammary area. The matter is being further investigated.

Faculty of Medicine, W. C. Osman Hirl.

University of Ceylon,

Colombo.

Nov. 25.

REFERENCES

Schultz, A. H., J. of Mammalogy, 2, 194 (1921).

Sonntag, C., Proc. Zool. Soc. (1922).

Wislocki, G. B., and Schultz, A. H., J. of Mammalogy, 6, 236 (1925). 